yellowish, the other veins hardly discernible; apical branch of the subcosta lacking; radial area open also at the distal end. Length: 3.0-3.5 $\mathrm{mm}$.

Range. South Africa: Salísbury, $5050 \mathrm{ft.}$ (F. L. Snow coll.). Types. 1 female and 1 male cotype in the collection of the Kansas State Museum; and 1 male cotype in the author's collection.

One of the male specimens is marked as collected in June, 1900; the other male and the female in Dec. 1900. In Das Tierreich, in Dalla Torre and Kieffer's key the species would run down to $A$. coriacea from which it is distinct in having all parts of the thorax black and the legs uniformly rufous-brown. The genus has not heretofore been known from Africa south of the north coast.

\title{
ON THE VARIATION OF TABANUS ATRATUS FABRICIUS.
}

\author{
By Charles W. Johnson, \\ Boston Society of Natural History.
}

This species, in its distribution along the Atlantic coast from Maine to Florida, is subject to considerable variation, which fact was referred to by Osten Sacken in his Prodrome (Memoirs Boston Soc. Nat. Hist., vol. II). On page 455 he says: "Northern specimens, for instance those found around Boston, often have the wings pale brown, even yellowish brown toward the posterior margin." Professor Hine in describing this form as T. nantuckensis from Nantucket, seems to have overlooked this reference, for he says: "There is reason to believe that this insect has become isolated on the Island for it has not been taken elsewhere so far as I can find."

\section{Tabanus atratus var. nantuckensis Hine}

Tabanus nantuckensis Hine, Ohio Jour. Sci., p. 271, 1917.

At most this is only a variety of $T$. atratus, apparently confined to the New England coast. Its "smaller size" does not count, for I have typical T. atratus as small as nantuckensis $(20 \mathrm{~mm}$.). This leaves for consideration only the color of the wings-dark brown with the posterior half or more, yellowish brown, as a distinguishing character, which in a large series from along the coast merges into 
typical atratus. The series before me referable to nantuckensis show the following distribution:

N. H. Rochester, Sept. 8 (A. M. Wilcox).

Mass. Boston, July 10 (H. M. Parshley); Cohasset, July 24 (Owen Bryant); New Bedford and Horse Neck Beach, Aug. 9 (Dr. G deN. Hough); N. Tisbury, July 21 (Dr. J. A. Cushman); Tuckerneck, July 21 (Dr. G. M. Allen); Muskeget, July 7 (W. S. Brooks); Hyannisport, July 4, Woods Hole, July 25, and Wellfleet, Aug. 16 (C. W. Johnson).

R. I. Block Island, Aug. 28, 1891 (A. P. Morse).

In this same region, typical atratus has been taken at the following places: Brookline, Auburndale, Sherborn, Framingham, Falmouth, Chatham and Woods Hole, Mass.

Tabanus atratus var. fulvopilosus var. nov.

This is another interesting variety which Osten Sacken refers to as follows: "The most remarkable variety, however, I received from Florida (Indian River, E. Palmer; Haulover Beach, March 12-14, Messrs. Hubbard and Schwarz); the thorax on each side bears a fringe of golden yellow hairs, not a trace of which is visible in ordinary specimens. I have four specimens from Florida, and two from some other southern locality not nearer defined, which show this peculiarity."

Fine examples of this variety were collected by Mr. S. E. Cassino at Orlando, Fla., in April, and by the writer on Anastasia Island, St. Augustine, Fla., April 21, 1919. I also collected a specimen at Avalon, N. J., July 19, 1891. Another specimen was captured at Cold Spring, near Cape May, N. J., June 24, 1903, by Mr. H. L. Viereck. The specimens from New Jersey have wings of a uniform dark brown approaching nantuckensis. A specimen of nantuckensis (from Nantucket) shows a slight trace of yellow pile above the base of the wings and lower edges of the post-alar callosities.

Another interesting variation of the more typical atratus, represented by two males and a female from Anastasia Island, Fla., April 12-19, has the black of the wings confined to broad margins along the veins, leaving subhyaline spaces between, giving the wings a striped appearance. A male of nantuckensis from Muskeget is similarly marked on the anterior half of the wings. 
These varietal names may seem perhaps unnecessary, but when one has already been referred to as a species by one of our leading authorities in this family, it shows how striking the variations are when isolated. There is a peculiar significance in the fact that these variations are apparently confined to the immediate seaboard, and their abundance there would indicate that they probably breed in the adjacent salt or brackish marshes. The question arises do these diversified conditions affect the species and give rise to these variations. On the other hand there is a similar though less pronounced variation in Tabanus trispilus. From New Jersey southward is found the typical form with dark brown wings, but to the northward the wings are much lighter in color, representing the var. sodalis Will. Another Tabanid, Chrysops fuliginosus or plangens, which is strictly a coastal species, distributed from Maine to Florida, shows considerable variation in the color of its wings, even in the same sex. Florida specimens have a distinct subhyaline streak dividing the apical spot from the crossband. Specimens from New Jersey northward have the brown of the wings more diffused and the streak less clearly defined.

\title{
A NEW SPECIES OF THE GENUS ULIDIA.
}

\author{
By Charles W. Johnson, \\ Boston Society of Natural History.
}

In a collection of Ortalidæ sent to me by Mr. E. P. Van Duzee for determination was the following apparently new species.

\section{Ulidia similis sp. nov.}

Head red, front punctate, each puncture bearing a short black hair, orbits pruinose, ocellar triangle black, one inner and one outer vertical and two post-vertical bristles, antennæ, palpi and proboscis reddish, arista blackish, thickened at the base. Thorax reddish, the disk black, covered with a grayish pollen and showing in a certain light two narrow dark vittæ, pleura red, between the front and middle coxæ blackish, two post-humerals, one pre-sutural, two supra-alar, one dorso-central, one notopleural, one mesopleural, and one sternopleural bristle, scutellum red, tips of the tarsi 

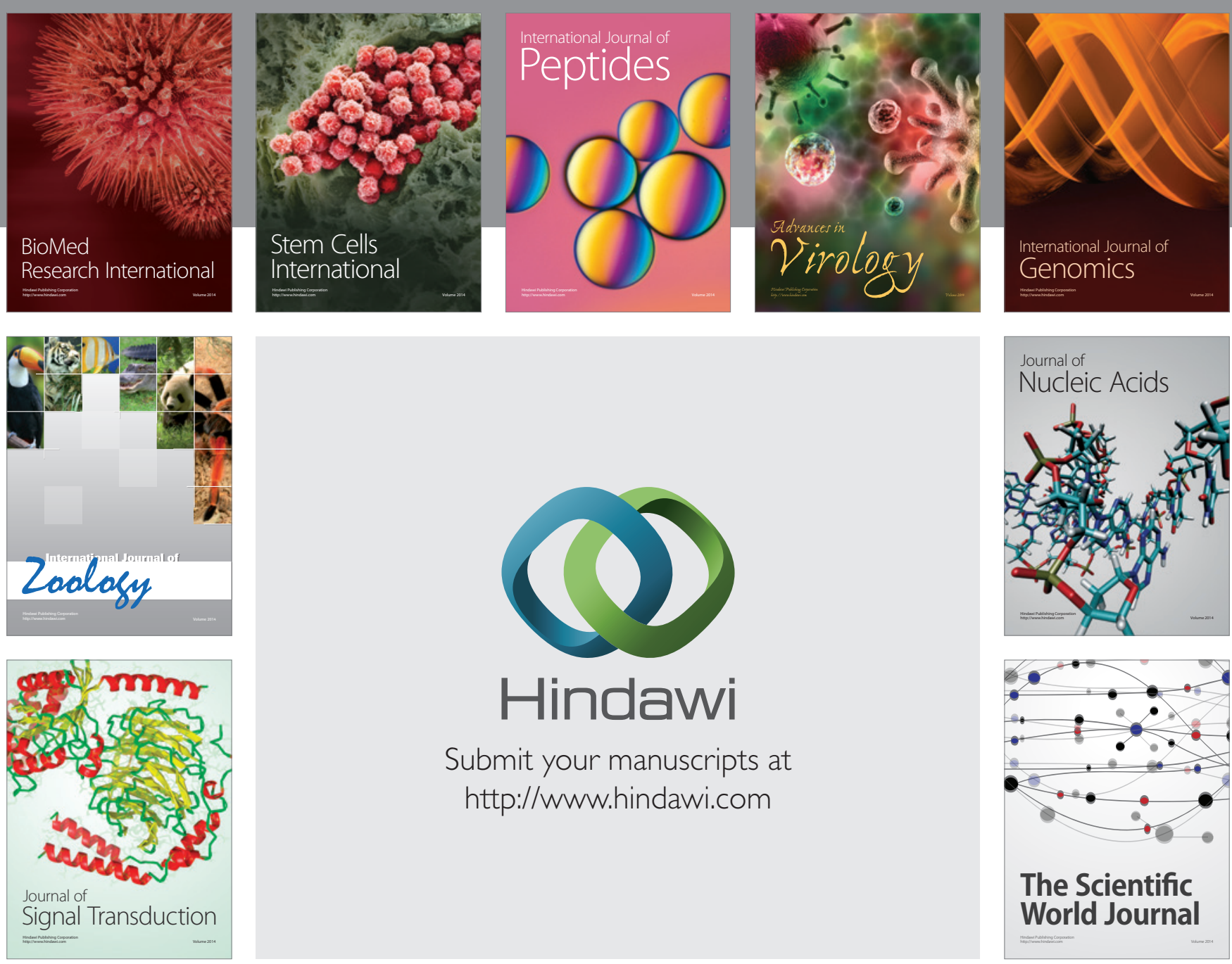

Submit your manuscripts at

http://www.hindawi.com
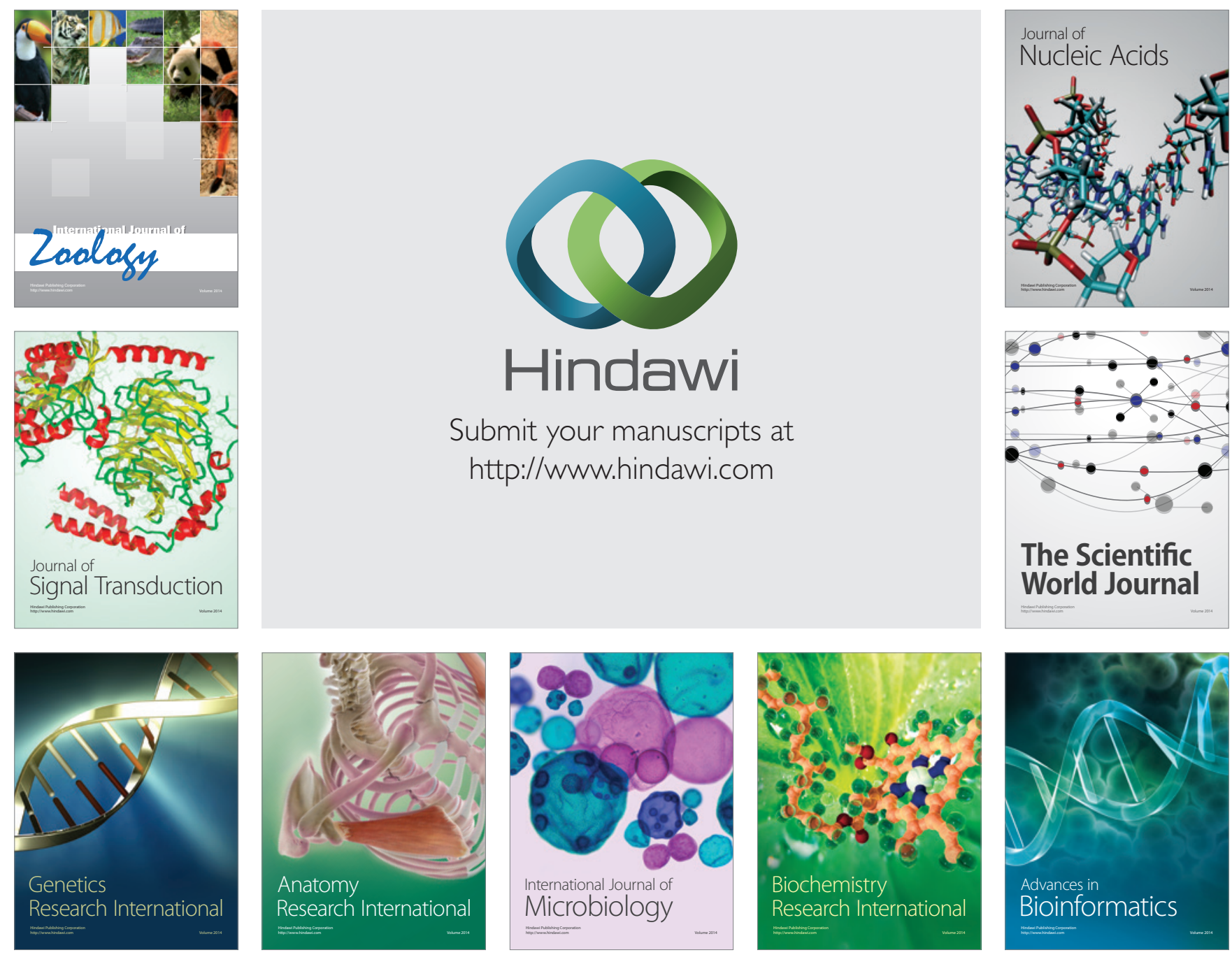

The Scientific World Journal
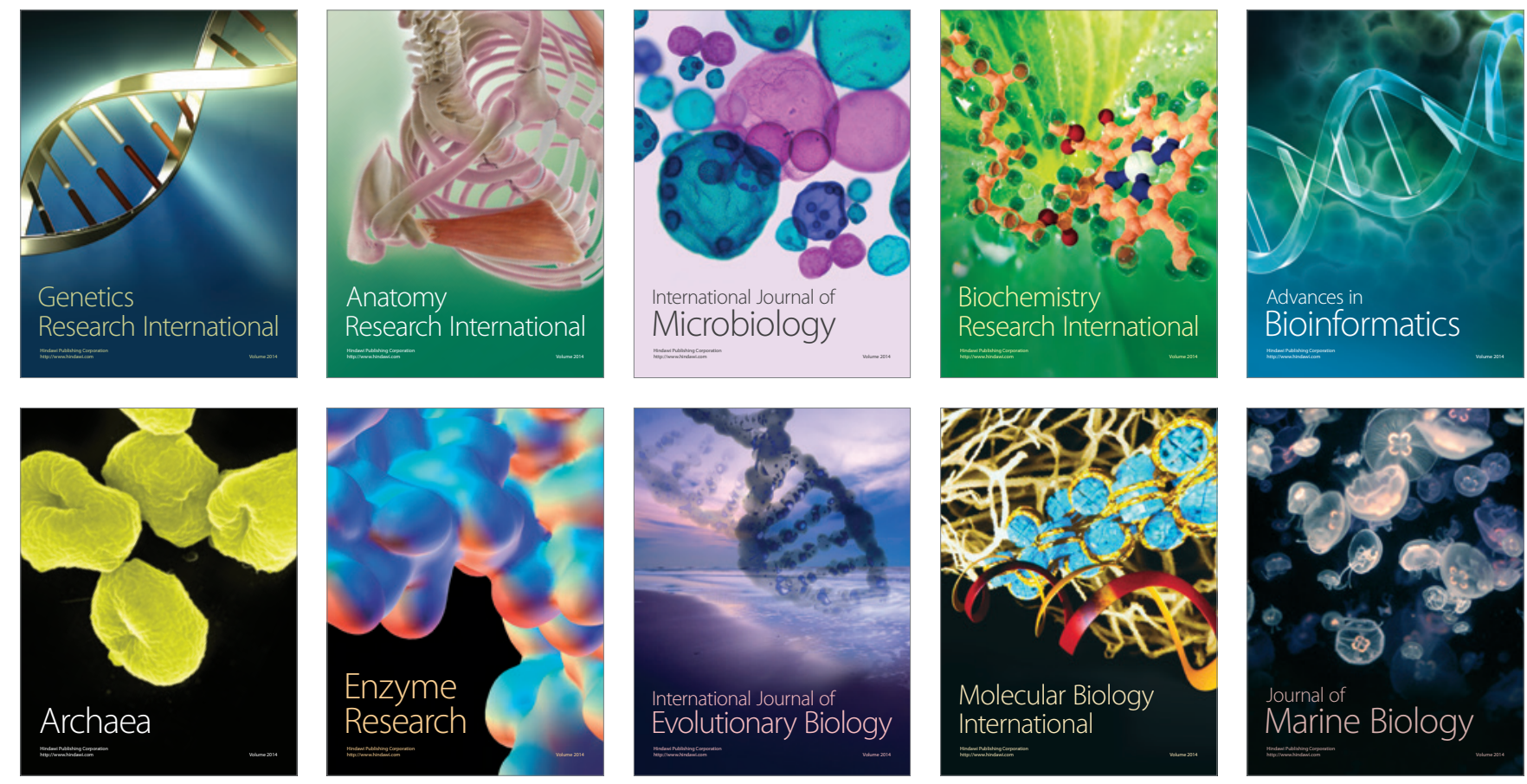